\title{
Evaluation of Hypogammaglobulinemia in Chronic Lymphocytic Leukemia Patients and Its Relation to Poor Prognostic Factors
}

\author{
Kronik Lenfositik Lösemi Hastalarında Hipogamaglobulineminin ve Olumsuz \\ Prognostik Faktörler ile ilişkisinin Değerlendirilmesi \\ ๑ Mesut Ayer, ๑ Çağan M. Akay*, ๑ Fatma Aylin Ayer*, ๑ Deniz Özmen**, ๑ Tayfun Elibol*** \\ University of Health Sciences, Haseki Training and Research Hospital, Clinic of Hematology, Istanbul, Turkey \\ *University of Health Sciences, Haseki Training and Research Hospital, Clinic of Internal Medicine, Istanbul, Turkey \\ **Istanbul University Cerrahpaşa Faculty of Medicine, Department of Hematology, Istanbul, Turkey \\ ***Marmara University, Pendik Training and Research Hospital, Clinic of Hematology, Istanbul, Turkey
}

\section{Abstract}

\begin{abstract}
Aim: Chronic lymphocytic leukemia (CLL) is a heterogenous disease with variable clinical course. Rai staging system is used for at least 40 years to predict prognosis and need for treatment but more prognostic factors are needed. Infections have been known to have a significant impact on patients with CLL. It is postulated that hypogammaglobulinemia accounts for the high infection rate. The severity of hypogammaglobulinemia is correlated with disease stage and duration.
\end{abstract}

Methods: Data of patients who were diagnosed with CLL according to the the National Cancer Institute Working Group criteria were analyzed retrospectively. The patients were classified according to absolute lymphocyte count, immunoglobulin (Ig) levels, Rai stage, organomegaly, mass lymphadenopathy, lymphocyte doubling time (LDT), presence of B symptoms and treatment status.

Results: We found that low IgA levels were associated with LDT and splenomegaly indicating disease burden and activity. The patients with low $\lg \mathrm{A}$ and $\lg \mathrm{M}$ levels received more treatment than others with normal Ig levels.

Conclusion: In our study, we could not find a significant relationship between the stage and Ig levels but low IgA and IgM levels were significantly associated with need for treatment. Therefore, we suggest measuring $\lg \mathrm{A}$ and $\operatorname{lgM}$ levels which is a simple and inexpensive test, to predict which patients may need treatment and should be observed closely.

Keywords: Chronic lymphocytic leukemia, hypogammaglobulinemia, chronic lymphocytic leukemia prognosis, immunoglobulins
Amaç: Kronik lenfositik lösemi (KLL) değişik klinik gidiş gösteren heterojen bir hastalıktır. Rai evreleme sistemi 40 yıldan uzun süredir prognozu ve tedavi intiyacını belirlemekte kullanılmakla beraber daha fazla prognostik faktöre intiyaç vardır. Enfeksiyonların KLL hastalarında önemli etkileri olduğu ve enfeksiyon sıklı̆ındaki artışta hipogamaglobulineminin etkisi olduğu bilinmektedir. Hipogamaglobulineminin şiddeti ile hastalığın evre ve süresi ile ilişkilidir.

Yöntemler: Ulusal Kanser Enstitüsü Çalışma Grubu kriterlerine göre KLL tanısı almış olan hastaların verileri retrospektif olarak analiz edilmiştir. Hastalar, mutlak lenfosit sayısı, immünoglobulin (lg) düzeyleri, Rai evresi, organomegali, lenfadenopati durumu, lenfosit sayısı ikiye katlanma zamanı, B semptomlarının varlığı ve tedavi durumuna göre sınıflandırılmıştır.

Bulgular: Düşük IgA düzeylerinin hastalık yükünü ve aktivitesini gösteren lenfosit sayısı ikiye katlanma zamanı ve splenomegali ile ilişkili olduğunu bulduk. Düşük lgA ve IgM düzeylerine sahip olan hastaların normal Ig düzeylerine sahip olanlara göre daha fazla tedavi aldıklarını saptadık.

Sonuç: Çalışmamızda, hastalık evresi ile Ig düzeyleri arasında anlamlı bir ilişki bulamadık fakat düşük $\lg A$ ve $\lg \mathrm{M}$ düzeyleri ile tedavi ihtiyacı arasında anlamlı bir ilişki saptadık. Bu nedenle, hastaların tedavi intiyacını belirlemede basit ve ucuz birer test olan lg düzeylerinin ölçülmesini ve yakın takibini öneriyoruz.

Anahtar Sözcükler: Kronik lenfositik lösemi, hipogamaglobulinemi, kronik lenfositik lösemi prognoz, immünoglobulinler 


\section{Introduction}

Chronic lymphocytic leukemia (CLL), is characterized by accumulation of mature $\mathrm{B}$ lymphocytes in peripheral blood, bone marrow, spleen and lymph nodes $(1,2)$. Lymphocytes are recognised by the expression of at least one of the $B$ antigens which is accompanied by expression of $T$ cell marker $\operatorname{CD} 5(3,4)$. Generally, lymphocytosis $\left(>5 \times 10^{9}\right)$ is found, but in minority of cases, presence of lymphadenopathy is the major presentation (5). CLL is the most common form of leukemias. Annually, 1500 new cases are diagnosed in the United States of America $(6,7)$. Average age at diagnosis is 65 years (1). Each year, 4500 Americans die from CLL complications (8).

Infections have been known to have a significant impact on clinical course of patients with CLL. 50-60\% of patients are lost due to infections. It is postulated that hypogammaglobulinemia accounts for the high infection rate. The severity of hypogammaglobulinemia is correlated with the stage and duration of the disease. Hypogammaglobulinemia is probably related to non-clonal CD5 (-) B cell abnormality and down-regulation of B cell Ig synthesis by large granular lymphocytes found in CLL patients. There is no consensus about deficiency of which class of Igs causes susceptibility to infections (9-12).

In this study, we aimed to investigate the frequency of hypogammaglobulinemia in CLL patients and its relationship with poor prognostic factors.

CLL is a heterogeneous disease with variable clinical course. The Rai staging system has been used for at least 40 years to predict prognosis and need for treatment but more prognostic factors are needed. Conventional clinical prognostic factors are Rai or Binet stage, lymphocyte doubling time (LDT) and bone marrow infiltration pattern. Biological prognostic factors are elevated serum beta-2 microglobulin, thymidin kinase and soluble CD23 levels, presence of p53 expression, somatic mutations in immunoglobulin (Ig), variable heavy chain region, CLL cell surface expression of CD38, intracellular zeta-associated protein-70 (ZAP-70) positivity, some chromosomal abnormalities (e.g. del 17p), and more than 10\% prolymphocytes in peripheral blood (13-23).

\section{Methods}

Data of patients, who were diagnosed with CLL according to the National Cancer Institute Working Group criteria, were analyzed retrospectively. Absolute lymphocyte, platelet counts, hemoglobin and IgG levels at the time of diagnosis were recorded. The patients were classified according to absolute lymphocyte count, Ig levels, Rai and modified Rai stage, organomegaly, mass lymphadenopathy (>7 cm LDT, presence of B symptoms, and treatment status). $\lg \mathrm{A}, \lg \mathrm{G}$ and $\lg \mathrm{M}$ levels were analyzed by immunoturbidimetry (Beckman Coulter AU2700, California).

Study assessments and methods were approved by the local Institutional review board (Haseki Training and Research Hospital Ethics Committee, no: 28R/2018, dated 08.05.2018) and were conducted in accordance with the current version of the Helsinki Declaration. Written informed consent was obtained from all patients for inclusion and publication of anonymized data.

\section{Statistical Analysis}

Statistical analysis was done using SPSS version 16.0 statistical program. To evaluate the relationship between Ig levels and variables, the Student's t-test, Mann-Whitney $U$ test, Fisher's exact test, and a chi-square were used. Correlation analyses were made by Pearson's correlation coefficient. A p value of less than 0.05 was considered statistically significant.

\section{Results}

Sixty six patients (37 male, 29 female) were enrolled in the study. Patient characteristics are shown in Table. The median age was 69 (range: 41-86) years. The median age was 74 for stage 0,67 for stage 1, 61 for stage 2 , and 58.5 for stage 4 . Age and Rai stages were reversely proportional $(p=0.021)$. Ig levels were not correlated with age and gender.

Percentage of Ig levels below reference values for each Ig class were $21.2 \%$ for $\lg A(<70 \mathrm{mg} / \mathrm{dL}), 10.6 \%$ for $\operatorname{lgG}(<700 \mathrm{mg} / \mathrm{dL})$, and $37.9 \%$ for $\operatorname{lgM}(<40 \mathrm{mg} / \mathrm{dL})$. We could not find a significant correlation between $\mathrm{lg}$ levels and Rai stage. IgA and IgM levels were significantly lower in patients who received treatment $(p=0.011$ and $\mathrm{p}=0.030$, respectively). The median absolute lymphocyte count was $25900 / \mathrm{mm}^{3}\left(2900-131000 / \mathrm{mm}^{3}\right)$. Lower IgA $(<70 \mathrm{mg} / \mathrm{dL})$ and $\mathrm{lgM}$ levels $(<40 \mathrm{mg} / \mathrm{dL}$ ) were related to higher absolute lymphocyte levels $(p=0.17$ and $p=0.10$, respectively). Lymphocyte counts were found to be statistically significantly increased with disease progress $(p<0.001)$.

Lower Ig levels were not correlated with presence of B symptoms. Shorter LDT ( $<6$ months) was significantly correlated with low IgA levels $(p=0.030)$ and higher Rai stage $(p=0.0001)$.

Of 28 patients, in whom genetic analysis was made, karyotype abnormality was found in only eight patients. One patient had 46,XX/complex karyotype, one patient had $47, X Y+8$, one patient had del 11q22, one patient had del 11q23, and four patients had del 13q. There was no significant correlation between Ig subtype and each genetic abnormality. Karyotype abnormality was not associated with need for treatment. 
Mass lymphadenopathy $(>7 \mathrm{~cm})$ was not related with low Ig levels, but strongly correlated with higher Rai stages $(p<0.001)$. Only low levels of IgA was significantly related with splenomegaly $(p=0.001)$.

\section{Discussion}

$\mathrm{CLL}$ is the most frequent leukemia type in adults and has a variable clinical course. Infections are attributed mainly to hypogammaglobulinemia. Other risk factors are defects in cellular immunity and complement system, and immunosuppressive treatment applied to the patients. Our goal was to investigate the frequency of hypogammaglobulinemia and its relationship with poor prognostic factors.

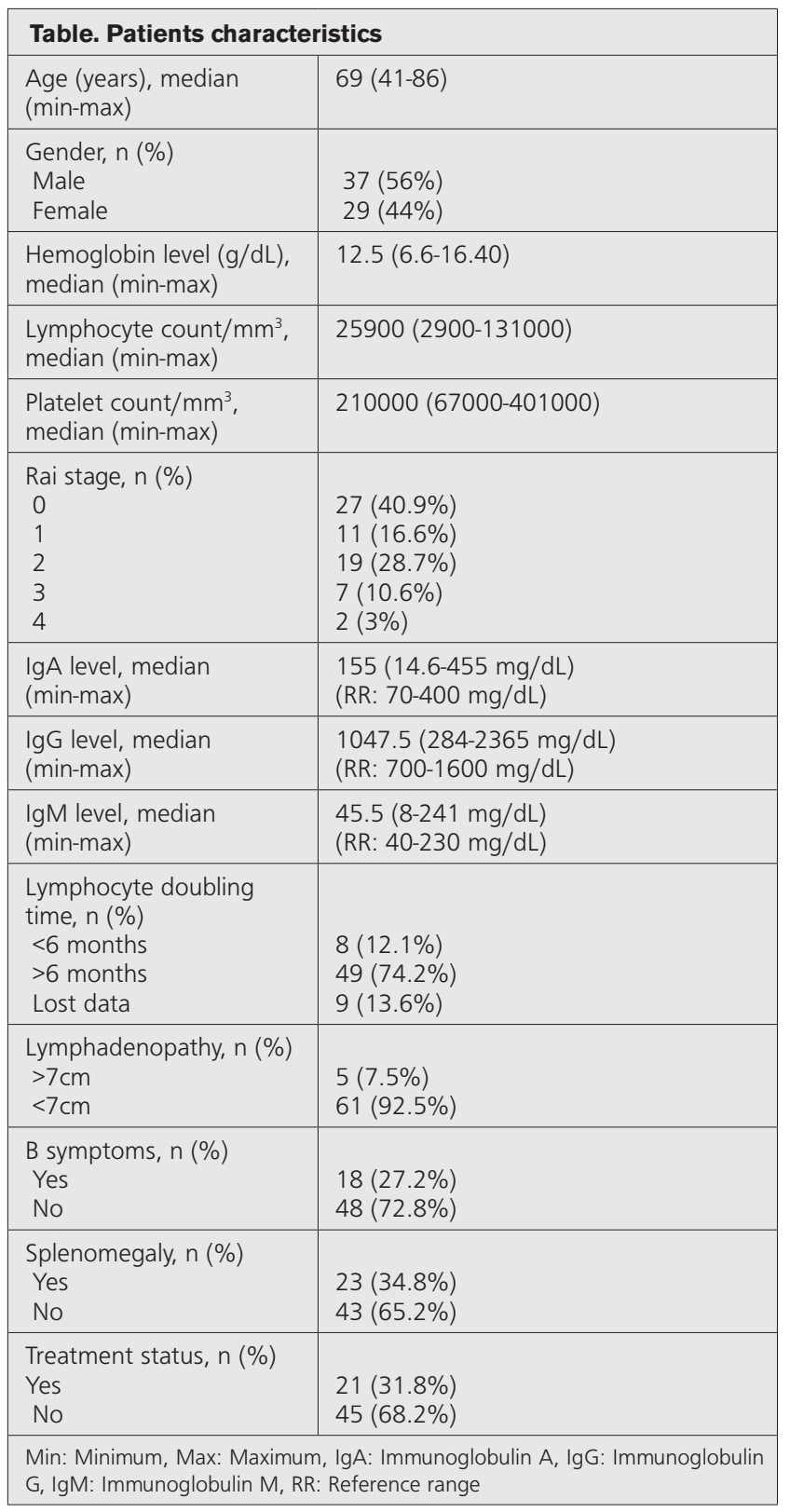

Parikh et al. (24) divided 3168 patients into two groups as under and over 55 years age and found that $44 \%$ of patients younger than 55 years of age had stage $0,53 \%$ had stage $1-2,3 \%$ had stage $3-4$ disease. $57 \%$ of patients over 55 years had stage $0,37 \%$ had stage $1-2$, and $6 \%$ had stage 2-4 disease. Younger patients presented mostly with stage $1-2$ disease. In the same study, $66 \%$ of patients under 55 years and $67 \%$ of patients over 55 years were male. In their study, Mauro et al. (25) also found that of 335 patients $65 \%$ were male and $35 \%$ were female. Another study evaluated $71 \mathrm{CLL}$ patients of whom $76 \%$ were male, $24 \%$ were female and median age was 58 years. In the same study, $16.9 \%$ of patients were having stage $0,69 \%$, stage $1-2$ and $14.1 \%$ were having stage $3-4$ disease. In our study $56 \%$ were male, $44 \%$ were female, the maleto-female ratio was 1.27:1 and the median age was 69 years (range: $41-86)$. Twenty-seven patients $(40.9 \%)$ had stage $0,11(16.7 \%)$, stage $1,19(28.8 \%)$, stage II, seven $(10.6 \%)$, stage III, and two patients (3\%) had stage IV disease. Compared to the literature, our male-to-female ratio was lower. The number of patients with advanced disease was higher because our clinic is a center where patients requiring treatment are commonly referred.

In previous studies, a significant relationship between absolute lymphocyte count and survival or response to treatment could not be demonstrated $(25,26)$. In our study, we found a strong correlation between disease stage and absolute lymphocyte count $(p=0.001)$. Also, patients with low IgA and IgM levels appeared to have higher absolute lymphocyte count, but there was no significant relationship between IgG and absolute lymphocyte count. Although not accepted as a poor prognostic factor in the literature, we believe further research are needed to elicit the importance of this variable which is frequently used during the follow-up of patients $(27,28)$.

In several studies, chromosomal abnormalities have been reported in 53-77\% of CLL patients (29-31). The most frequently genetic alterations were del $13 q$, trisomy 12 , del $11 q$, del $17 p$ and del $6 q$. It is known that, del $11 q$ and del $17 p$ are associated with high disease activity (30). el Rouby et al. (32) investigated p53 mutation in CLL patients and found that p53 mutation was associated with progressed disease. In our study, fluorescence in situ hybridization (FISH) analysis was made in 29 of 66 patients. In eight patients, different genetic abnormalities were found. Compared to the literature, the rate of FISH positivity in our study was low due to lack of genetic information. In four patients, del 13q, which is associated with good prognosis, was found. Poor prognostic del 11q was found in two patients, del 17p was not found in any of the patients. Due to low number of patients and poor prognostic cytogenetic abnormalities, we could not find 
an association between karyotype abnormalities and high stage.

It is advised to use the International Workshop on CLL (iwCLL) criteria to initiate treatment in CLL patients (33). Otherwise, absolute lymphocyte count and hypogammaglobulinemia in the absence of iwCLL criteria do not indicate treatment. In their study, Parikh et al. (34) found that $26 \%$ of 1485 CLL patients had hypogammaglobulinemia. Poor prognostic factors like advanced Rai stage and CD49d expression were associated with greater risk of hypogammaglobulinemia and patients with low Ig levels progressed rapidly. In our study, we could not find a significant relationship between hypogammaglobulinemia and disease stage ( $p$ value for $\lg \mathrm{A}, \operatorname{Ig} \mathrm{G}$ and $\lg \mathrm{M}: 0.162,0.487$ and 0.188 , respectively). Shvidel et al. (35) analyzed Ig levels in 1113 patients from the Israeli CLL Study Group diagnosed with Binet A CLL in 25 years and found that age above 65 , male gender, CD38 and ZAP-70 expression, elevated beta-2 microglobulin levels and lymphadenopathy were associated with shorter survival time but no relationship of survival time with hypogammaglobulinemia and paraproteinemia was found. Patients with low IgA levels needed treatment more than other groups.

In several studies, shorter LDT was found to be associated with poor prognosis $(36,37)$. In our study, similar to the literature, there was a significant correlation between LDT and disease stage $(p<0.001)$. Additionally, we found that patients with LDT shorter than six months, had lower IgA levels $(p=0.030)$. According to the iwCLL guideline, a LDT of shorter than six months or elevation of lymphocyte count by $50 \%$ in two months are indications for treatment. Therefore, it is advisable to more frequently follow patients with a Rai stage 0-1-2 or Binet stage A-B and with low IgA levels.

In previous studies, it has been shown that hypogammaglobulinemia may precede CLL years before the disease emerges (38). In the sudy by Parikh et al. (34), it was found that low IgG levels were associated with progressed disease and high CD49d expression. Time to first treatment was shorter in patients with low lg levels. In our study, we could not find a significant relationship between patients' stages and Ig levels ( $p$ value for IgA, IgG and IgM respectively; $0.162,0.487$ and 0.188 ), but low IgA and IgM levels were significantly associated with need for treatment ( $p=0.011$ and $p=0.030$, respectively).

In the literature, it is mentioned that del $11 \mathrm{q}$ positivity is associated with mass lymphadenopathy, both indicating poor prognosis $(39,40)$. In our study, mass lympadenopathy was related to advanced stage but not to low Ig levels ( $p$ value for IgA, IgG and IgM: 0.94, 0.462 and 0.36, respectively).
In several studies, it has been shown that splenomegaly is related to disease burden and poor prognostic factors $(41,42)$. In our study, patients with low IgA levels had more severe splenomegaly but there was no significant relationship between Ig levels and B symptoms.

\section{Conclusion}

In our study, we found that low IgA levels were associated with LDT and splenomegaly which indicate disease burden and activity. Patients with low IgA and $\lg \mathrm{M}$ levels received more treatment than others with normal Ig levels. Therefore, we suggest measuring IgA and IgM levels which is a simple and inexpensive test, to predict which patient may need treatment and should be observed closely.

\section{Authorship Contributions}

Surgical and Medical Practices: M.A. Concept: M.A. Design: M.A. Data Collection or Processing: M.A., C..M.A. Analysis or Interpretation: M.A., Ç.M.A., F.A.A., D.Ö., T.E. Literature Search: Ç.M.A., D.Ö., T.E., Writing: M.A., Ç.M.A., D.Ö.

Conflict of Interest: No conflict of interest was declared by the authors.

Financial Disclosure: The authors declared that this study received no financial support.

\section{References}

1. Chiorazzi N, Rai KR, Ferrarini M. Chronic lymphocytic leukemia. N Engl J Med 2005;352:804-15.

2. Rozman C, Montserrat E. Chronic lymphocytic leukemia. N Engl J Med 1995;333:1052-7.

3. Matutes E, Owusu-Ankomah K, Morilla R, et al. The immunological profile of B-cell disorders and proposal of a scoring system for the diagnosis of CLL. Leukemia 1994;8:1640-5.

4. Moreau EJ, Matutes E, A'Hern RP, et al. Improvement of the chronic lymphocytic leukemia scoring system with the monoclonal antibody SN8 (CD79b). Am J Clin Pathol 1997; 108:378-82.

5. Harris NL, Jaffe ES, Stein $\mathrm{H}$, et al. A revised European-American classification of lymphoid neoplasms: a proposal from the International Lymphoma Study Group. Blood 1994;84:136192.

6. Morton LM, Wang SS, Devesa SS, Hartge P, Weisenburger DD, Linet MS. Lymphoma incidence patterns by WHO subtype in the United States, 1992-2001. Blood 2006;107:265-76.

7. Zent CS, Kyasa MJ, Evans R, Schichman SA. Chronic lymphocytic leukemia incidence is substantially higher than estimated from tumor registry data. Cancer 2001;92:1325-30.

8. Maurer C, Hallek M. [Chronic lymphocytic leukemia]. Dtsch Med Wochenschr 2013;138:2153-66.

9. Molica S, Levato D, Levato L. Infections in chronic lymphocytic leukemia. Analysis of incidence as a function of length of follow-up. Haematologica 1993;78:374-7. 
10. Hudson RP, Wilson J. Hypogammaglobulinemia and chronic lymphatic leukemia. Cancer 1960;13:200-4.

11. Itälä M, Helenius $H$, Nikoskelainen J, Remes K. Infections and serum IgG levels in patients with chronic lymphocytic leukemia. Eur J Haematol 1992;48:266-70.

12. Kay NE, Perri RT. Evidence that large granular lymphocytes from B-CLL patients with hypogammaglobulinemia down-regulate B-cell immunoglobulin synthesis. Blood 1989;73:1016-9.

13. Cheson BD, Bennett JM, Grever M, et al. National Cancer Institute-sponsored Working Group guidelines for chronic lymphocytic leukemia: revised guidelines for diagnosis and treatment. Blood 1996;87:4990-7.

14. Byrd JC, Stilgenbauer S, Flinn IW. Chronic lymphocytic leukemia. Hematology Am Soc Hematol Educ Program 2004:163-83.

15. Hamblin TJ. Prognostic markers in chronic lymphocytic leukaemia. Best Pract Res Clin Haematol 2007;20:455-68.

16. Melo JV, Catovsky D, Galton DA. The relationship between chronic lymphocytic leukaemia and prolymphocytic leukaemia. I. Clinical and laboratory features of 300 patients and characterization of an intermediate group. $\mathrm{Br} J$ Haematol 1986;63:377-87.

17. Keating MJ. Chronic lymphocytic leukemia. Semin Oncol 1999;26(5 Suppl 14):107-14.

18. Källander CF, Simonsson B, Hagberg H, Gronowitz JS. Serum deoxythymidine kinase gives prognostic information in chronic lymphocytic leukemia. Cancer 1984;54:2450-5.

19. Sarfati M, Chevret S, Chastang C, et al. Prognostic importance of serum soluble CD23 level in chronic lymphocytic leukemia. Blood 1996;88:4259-64.

20. Gaidano G, Ballerini P, Gong JZ, et al. p53 mutations in human lymphoid malignancies: association with Burkitt lymphoma and chronic lymphocytic leukemia. Proc Natl Acad Sci USA 1991;88:5413-7.

21. Damle RN, Wasil T, Fais $F$, et al. Ig $\vee$ gene mutation status and CD38 expression as novel prognostic indicators in chronic lymphocytic leukemia. Blood 1999;94:1840-7.

22. Chan AC, Irving BA, Fraser JD, Weiss A. The zeta chain is associated with a tyrosine kinase and upon T-cell antigen receptor stimulation associates with ZAP-70, a 70-kDa tyrosine phosphoprotein. Proc Natl Acad Sci U S A 1991;88:9166-70.

23. Döhner H, Stilgenbauer S, Benner A, et al. Genomic aberrations and survival in chronic lymphocytic leukemia. N Engl J Med 2000;343:1910-6.

24. Parikh SA, Rabe KG, Kay NE, et al. Chronic lymphocytic leukemia in young ( $\leq 55$ years) patients: a comprehensive analysis of prognostic factors and outcomes. Haematologica 2014;99:140-7.

25. Mauro FR, De Rossi G, Burgio VL, et al. Prognostic value of bone marrow histology in chronic lymphocytic leukemia. A study of 335 untreated cases from a single institution. Haematologica 1994;79:334-41.
26. Mozaheb Z, Hasanzadeh NazarAbadi MH, Aghaee MA. Chronic lymphocytic leukemia and prognostic factors. Asian Pac J Cancer Prev 2012;13:3009-13.

27. Tsimberidou AM, Wen S, O'Brien S, et al. Assessment of chronic lymphocytic leukemia and small lymphocytic lymphoma by absolute lymphocyte counts in 2,126 patients: 20 years of experience at the University of Texas M.D. Anderson Cancer Center. J Clin Oncol 2007;25:4648-56.

28. Şermin A. Gazi üniversitesi Hematooji Bölümü'nde izlenen KLL hastalarının tedavi yanıtlarının değerlendirilmesi, Tıpta Uzmanlık Tezi; 2013.

29. Döhner H, Stilgenbauer S, Benner A, et al. Genomic aberrations and survival in chronic lymphocytic leukemia. N Engl J Med 2000;343:1910-6.

30. Jarosová $M$, Jedlicková $K$, Holzerová $M$, et al. Contribution of comparative genomic hybridization and fluorescence in situ hybridization to the detection of chromosomal abnormalities in B-cell chronic lymphocytic leukemia. Onkologie 2001;24:60-5.

31. Dewald GW, Brockman SR, Paternoster SF, et al. Chromosome anomalies detected by interphase fluorescence in situ hybridization: correlation with significant biological features of B-cell chronic lymphocytic leukaemia. $\mathrm{Br} J$ Haematol 2003;121:287-95.

32. el Rouby $S$, Thomas $A$, Costin $D$, et al. p53 gene mutation in B-cell chronic lymphocytic leukemia is associated with drug resistance and is independent of MDR1/MDR3 gene expression. Blood 1993;82:3452-9.

33. Hallek $M$, Cheson BD, Catovsky $D$, et al. Guidelines for the diagnosis and treatment of chronic lymphocytic leukemia: a report from the International Workshop on Chronic Lymphocytic Leukemia updating the National Cancer InstituteWorking Group 1996 guidelines. Blood 2008;111:5446-56.

34. Parikh SA, Shanafelt TD, Rabe $K G$, et al. Hypogammaglobulinemia In Patients With Previously Untreated Chronic Lymphocytic Leukemia: Clinical Correlates and Outcomes. Blood 2013;122:4178.

35. Shvidel L, Tadmor T, Braester A, et al. Serum immunoglobulin levels at diagnosis have no prognostic significance in stage $A$ chronic lymphocytic leukemia: a study of 1113 cases from the Israeli CLL Study Group. Eur J Haematol 2014;93:29-33.

36. Molica S, Alberti A. Prognostic value of the lymphocyte doubling time in chronic lymphocytic leukemia. Cancer 1987;60:2712-6.

37. Mozaheb Z, Hasanzadeh NazarAbadi MH, Aghaee MA. Chronic lymphocytic leukemia and prognostic factors. Asian Pac J Cancer Prev 2012;13:3009-13.

38. Tsai HT, Caporaso NE, Kyle RA, et al. Evidence of serum immunoglobulin abnormalities up to 9.8 years before diagnosis of chronic lymphocytic leukemia: a prospective study. Blood 2009;114:4928-32.

39. Tsimberidou AM, Tam C, Abruzzo LV, et al. Chemoimmunotherapy may overcome the adverse prognostic 
significance of 11q deletion in previously untreated patients with chronic lymphocytic leukemia. Cancer 2009:115:373-80.

40. Döhner $H$, Stilgenbauer $S$, James MR, et al. $11 q$ deletions identify a new subset of B-cell chronic lymphocytic leukemia characterized by extensive nodal involvement and inferior prognosis. Blood 1997;89:2516-22.
41. Del Poeta G, Maurillo L, Venditti A, et al. Clinical significance of CD38 expression in chronic lymphocytic leukemia. Blood 2001;98:2633-9.

42. Mauro FR, De Rossi G, Burgio VL, et al. Prognostic value of bone marrow histology in chronic lymphocytic leukemia. A study of 335 untreated cases from a single institution. Haematologica 1994;79:334-41. 